\title{
Epidemiological and Histopathological Features of Small Intestine Cancer in Cameroon: About 47 Cases
}

\author{
Jean Paul Ndamba Engbang1, 2, *, Servais Eloumou ${ }^{1,3}$, Amadou Fewou ${ }^{4,5}$, \\ Clémentine Essaga Essaga ${ }^{1}$, Bruno Djimeli Djougmo ${ }^{2}$, Gilbert Ateba ${ }^{3,6}$, Godefroy Simo ${ }^{7}$, \\ André Moune ${ }^{8}$ \\ ${ }^{1}$ Faculty of Medicine and Pharmaceutical Sciences, University of Douala, Douala, Cameroon \\ ${ }^{2}$ Laquintinie Hospital of Douala, Douala, Cameroon \\ ${ }^{3}$ Douala Gyneco - Pediatric Hospital, Douala, Cameroon \\ ${ }^{4}$ Douala General Hospital, Douala, Cameroon \\ ${ }^{5}$ Faculty of Medicine and Biomedical Sciences, The University of Yaoundé I, Yaoundé, Cameroon \\ ${ }^{6}$ Pravilna Laboratory, Douala, Cameroon \\ ${ }^{7}$ Bio-Medical and Cancer Center of Bafoussam, Bafoussam, Cameroon \\ ${ }^{8}$ Anapathos Laboratory, Douala, Cameroon
}

Email address:

Jean_pen@yahoo.ca (J. P. N. Engbang),jpauleng@gmail.com (J. P. N. Engbang)

${ }^{*}$ Corresponding author

\section{To cite this article:}

Jean Paul Ndamba Engbang, Servais Eloumou, Amadou Fewou, Clémentine Essaga Essaga, Bruno Djimeli Djougmo, Gilbert Ateba, Godefroy Simo, André Moune. Epidemiological and Histopathological Features of Small Intestine Cancer in Cameroon: About 47 Cases. Cancer Research Journal. Vol. 7, No. 4, 2019, pp. 136-142. doi: 10.11648/j.crj.20190704.13

Received: August 25, 2019; Accepted: September 9, 2019; Published: October 9, 2019

\begin{abstract}
Bakground: The small intestine represents the longest part of the digestive tract. The small bowel cancer is rare, but is increasing worldwide. Methods: Data was analysed retrospectively from the medical records concerning cancer of the small intestine histologically proven, from different histopathology laboratories in Cameroon, for 13 years (2004-2016). The variables studied were the frequency, age, gender, risk factors, location and histopathologic type Results: $3.34 \%$ (47 cases 11407) of digestive cancers observed during the period of study. There were 23 female and 24 male patients, with a mean age of $49,77 \pm 15,84$ ( 11 to 78 years), the sex ratio of men to women 1.04. The main risk factors were Intestinal polyp, adenomatous polyp and polyposis with 6 cases $25.00 \%$, respectively. The ileum location was the most represented with $47.37 \%$. Adenocarcinoma was the most frequent histological type with 33 cases (70.21\%). Conclusion: Small intestine cancer is the sixth malignant tumor of the digestive tract in Cameroon. The mean age of onset is 49.77 years with a relative male predominance. The most common histological type is adenocarcinoma.
\end{abstract}

Keywords: Small Intestine, Small Bowel, Cancers, Epidemiology, Histopathology, Cameroon

\section{Introduction}

Malignant tumors of small bowel are less frequent. Small intestine malignancies represent only 3 percent of all gastrointestinal tract neoplasms $[1,2]$. Despite that, small intestine cancers are increasing in developed world, with over $100 \%$ estimated incidence growth in the past four decades [3]. International data shows that the incidence is higher in North America, western Europe and Oceania than in Asia [4, 5]. Males are more likely to be diagnosed and die from, small intestine cancer than females [6]. In USA, the median age was 66 [3]. In some others African countries, the average age was 46 years ( $15-70$ years), 41,75 years ( 5 et 77 years) and 36 years old, in Morocco, Togo and Madagascar respectively [7-9]. Several authors have shown a link between some lesions and SBC like adenoma, familial polyposis, Crohn's disease, and coeliac disease [10-13]. Cancers of the small intestine are primarily of two etiologies: 
small bowel adenocarcinoma (SBA) which account for $40 \%$ of cases, and neuroendocrine tumors, accounting for another $40 \%[14,15]$. In Cameroon, a study conducted by Ngowe Ngowe et al in 2001 on 10 cases of tumors small Bowel in general at the Yaounde General Hospital, found only two malignant tumors including a carcinoid and Kaposi Angiosarcoma [16]. The scarcity of data on this pathology in Cameroon has led us to conduct this multicenter study to provide information on the epidemiology and histopathology of this disease in this part of the world.

\section{Methods}

This is a retrospective descriptive and analytical study of histologically proven malignant tumors of small bowel, diagnosed between January 2004 and December 2016. Data was obtained from histopathology, urology and oncology records of different health centers in five regions of Cameroon. The samples generally come from previously unresolved surgery, cancerology or gastroenterology departments. Once in the pathology departments, they are fixed at $10 \%$ formalin, and then the macroscopic study in which the pieces are cut. The pieces are dehydrated by passing through several tanks of alcohol at increasing concentrations, then included in paraffin, then cut with a microtome to a thickness of 5 micron. They are then deparaffinized by xylene lightening, and the staining is done with haematin-eosin followed by reading made using a microscope. The parameters studied were frequency, age, sex, histological type of the tumor. Data entry was done using computer based statistical Package for Social Sciences (SPSS) version 20. The elements of descriptive statistics were used to calculate the frequencies and proportions.

\section{Results}

\subsection{Frequency of Cancers by Segment of the Digestive Tract}

In total, 1407 cases of cancers of the gastrointestinal tract were collected, from 2004 to 2016. Small intestine (12 cases, $3.34 \%$ ) was in the sixth position after the stomach, the colon, the rectum, the anal and the esophageal cancer.

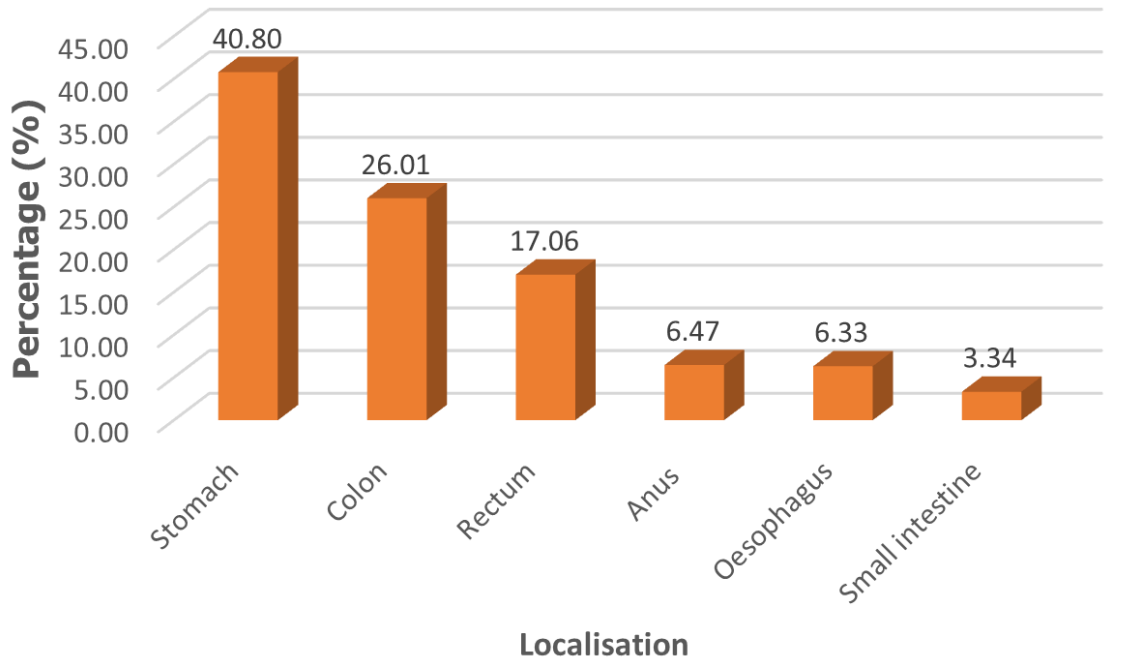

Figure 1. Distribution of cancers according to the segment of the digestive tube.

\subsection{Distribution by Sex}

As shown in table 1 , the male sex was represented by 24 cases $(51.06 \%)$ or $1.71 \%$ of all digestive cancers. The sex ratio was 1.04 .

Table 1. Distribution of digestive tract cancers by sex.

\begin{tabular}{|c|c|c|c|c|c|c|c|c|c|c|c|c|c|}
\hline \multirow{2}{*}{$\begin{array}{l}\text { Organ } \\
\text { Sex }\end{array}$} & \multicolumn{2}{|c|}{ Stomach } & \multicolumn{2}{|c|}{ Colon } & \multicolumn{2}{|c|}{ Rectum } & \multicolumn{2}{|l|}{ Anus } & \multicolumn{2}{|c|}{ Esophagus } & \multicolumn{2}{|c|}{$S$ intestine } & \multirow[t]{2}{*}{ Total } \\
\hline & $\mathbf{H}$ & $\mathbf{F}$ & $\mathbf{H}$ & $\mathbf{F}$ & $\mathbf{H}$ & $\mathbf{F}$ & $\mathbf{H}$ & $\mathbf{F}$ & $\mathbf{H}$ & $\mathbf{F}$ & $\mathbf{H}$ & $\mathbf{F}$ & \\
\hline Effective & 312 & 262 & 193 & 173 & 130 & 110 & 42 & 49 & 67 & 22 & 24 & 23 & 1407 \\
\hline$\%$ Effective & 22,17 & 18,62 & 13,72 & 12,30 & 9,24 & 7,82 & 2,99 & 3,48 & 4,76 & 1,56 & 1,71 & 1,63 & 100 \\
\hline Total & 574 & & 366 & & 240 & & 91 & & 89 & & 47 & & 1407 \\
\hline$\%$ Total & 40,80 & & 26,01 & & 17,06 & & 6,47 & & 6,33 & & 3,34 & & 100 \\
\hline
\end{tabular}

\subsection{Distribution by Age}

As shown in the Figure 2, the average age of diagnosis was $49,77 \pm 15,84$ (11 to 78 years). The majority of patients were between 50 and 59 years old ( 11 cases; $23.40 \%$ ).

In men, the average age was $51,52 \pm 13,67$ years with extremes ranging from 23 to 70 years old. In women the mean age of diagnosis was $48,17 \pm 19,33$ years with extremes ranging from 11 to 78 years old. 


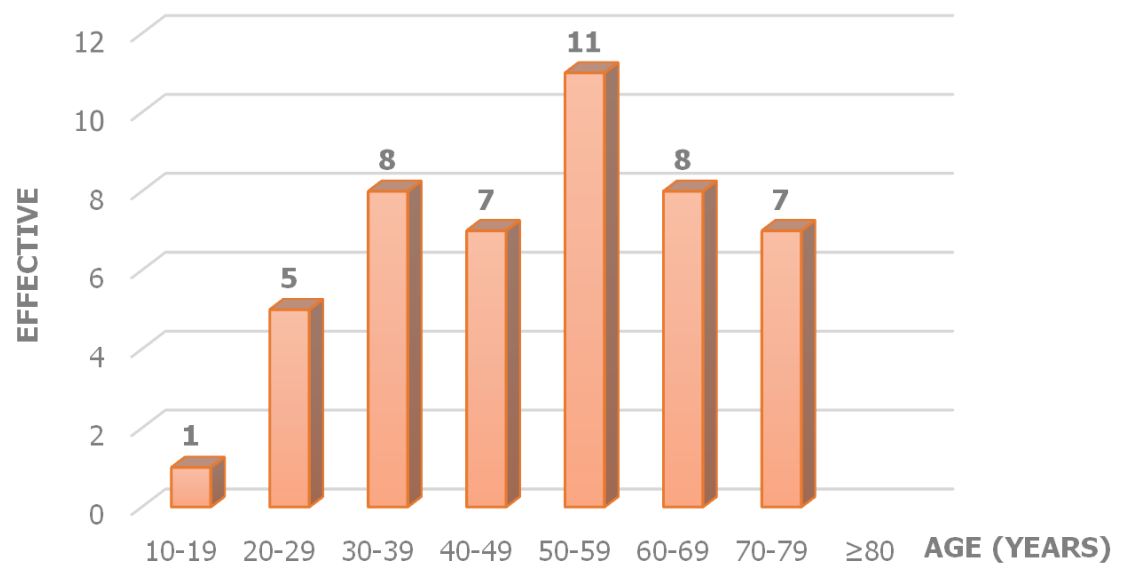

Figure 2. Distribution of patients by age group.

\subsection{Distribution According to Risk Factors}

Risk factors were highlighted in 24 patients. The most common were Intestinal polyp, adenomatous polyp and polyposis with 6 cases $25.00 \%$, respectively (Table 2).

Table 2. Factors associated with the risk of small intestine cancer.

\begin{tabular}{lll}
\hline Risk Factors & Effective & Percentage $\%$ \\
\hline intestinal Polyp & 6 & 25.00 \\
Polyposis & 6 & 25.00 \\
adenomatous polyp & 3 & 12.50 \\
Delicatessen & 3 & 12.50 \\
Alcohol & 3 & 12.50 \\
HIV & 3 & 12.50 \\
Total & 24 & 100.00 \\
\hline
\end{tabular}

\subsection{Tumor Localization}

Of the 19 lesions localized, as shown in Figure 3, the tumor was ileum localization in $47.37 \%$ of cases ( 9 cases), jejunum ( 7 cases, $36.84 \%)$.

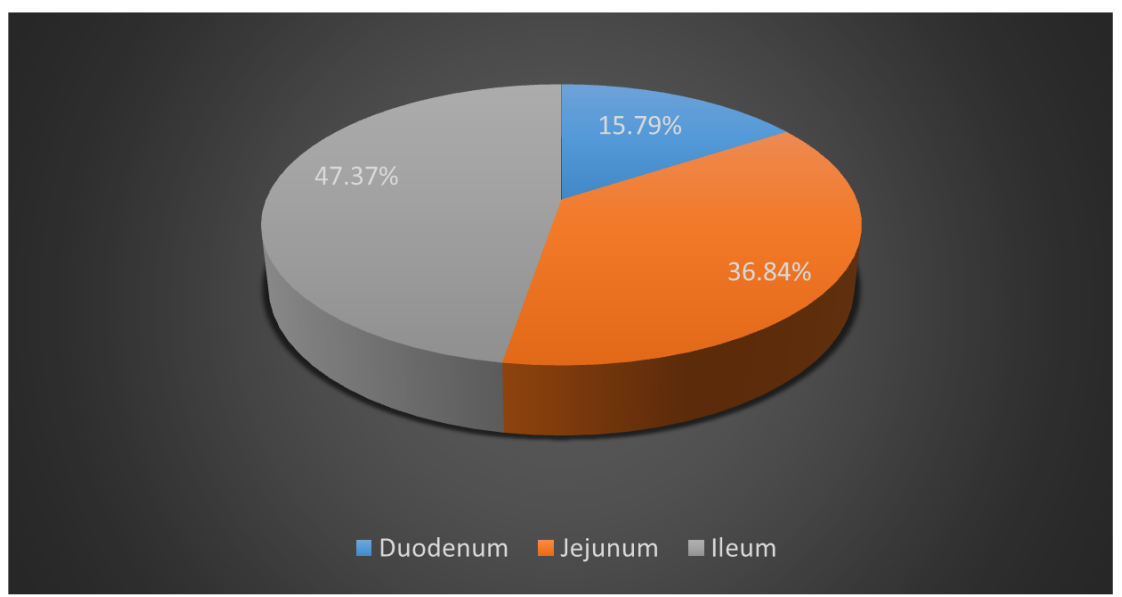

Figure 3. Distribution by localization.

\subsection{Anatomopathology}

\subsubsection{Types of Sampling}

The type of sample was specified on 30 cases, of which 18 $(60.00 \%)$ were derived from operative specimens and 12 $(40.00 \%)$ were biopsies.

\subsubsection{Histological Type}

The most common varieties were adenocarcinomas (33 cases, $70.21 \%$ ), followed by Non-Hogdkin's Malignant Lymphoma (NHML). Carcinoid was found principally before 40 and after 70 years old (Table 3 ). 
Table 3. Distribution by histological type.

\begin{tabular}{|c|c|c|c|c|c|c|c|c|c|c|}
\hline Histological Type & $0-9$ & $10-19$ & $20-29$ & $30-39$ & $40-49$ & $50-59$ & $60-69$ & $70-79$ & Total & $\%$ \\
\hline Adenocarcinoma & - & - & 1 & 6 & 5 & 11 & 7 & 3 & 33 & 70,21 \\
\hline NHML & - & 1 & 3 & 1 & 2 & - & 1 & 1 & 9 & 19,15 \\
\hline Carcinoid & - & - & 1 & 1 & - & - & - & 3 & 5 & 10,64 \\
\hline Total & - & 1 & 5 & 8 & 7 & 11 & 8 & 7 & 47 & 100,00 \\
\hline
\end{tabular}

NHML - Non-Hogdkin's Malignant Lymphoma

At the 3 principal subsites, all tumors showed a predilection for the ileum (Table 4).

Table 4. Distribution of histological types by location.

\begin{tabular}{|c|c|c|c|c|c|c|c|}
\hline \multirow{2}{*}{ Location } & \multicolumn{2}{|c|}{ ADK } & \multicolumn{2}{|c|}{ LMNH } & \multicolumn{2}{|c|}{ T Carcinoide } & \multirow{2}{*}{ Total } \\
\hline & $\mathbf{H}$ & $\mathbf{F}$ & $\mathbf{H}$ & $\mathbf{F}$ & $\mathbf{H}$ & $\mathbf{F}$ & \\
\hline Duodenum & 1 & 2 & - & - & - & - & 3 \\
\hline Jejunum & 3 & 2 & 1 & 1 & - & - & 7 \\
\hline Ileum & 5 & 1 & - & 1 & 1 & 1 & 9 \\
\hline Total & 9 & 5 & 1 & 2 & 1 & 1 & 19 \\
\hline
\end{tabular}

\section{Discussion}

The small bowel represents approximately 75 percent of the length and over 90 percent of the surface of the alimentary tract $(90 \%$ of the absorptive surface area of the gastrointestinal tract) $[1,2]$. The small intestine is located between the stomach and the large intestine and is the primary site of end absorption of nutrients from food, including proteins, lipids, and carbohydrates. It is comprised of three distinct regions: the duodenum, jejunum, and ileum. The duodenum is where most of the body's digestive enzymes are released [17].

In our study, cancer of the small intestine (12 cases, $3.34 \%$ ) was in the sixth position after the stomach, the colon, the rectum, the anal and the esophageal cancer. According to Neugut, malignant tumors of that organ account for less than $5 \%$ of all gastrointestinal cancers (GI) cancer cases [18]. Raghav and Siegel in their studies indicated that small bowel malignancies represent only 3 percent of all gastrointestinal tract neoplasms [1, 2]. In others series, Cancers of the small intestine or small bowel cancer (SBC) account for only $0.42 \%$ of total cancer cases and $2.3 \%$ of cancers of the digestive system in the United States; while in Canada, $0.37 \%$ and $1.78 \%$ respectively $[19,20]$. Finally, we can say that, malignant tumors of the small intestine are very rare compared to other gastrointestinal organs.

Several hypotheses have been put forward to explain the relative infrequency of small bowel. A small food transit time in the small intestine, which shortens the exposure of the mucosal lining to carcinogens, in addition to fluid circulation of alkaline intestinal chyme [21, 22]. The small intestine has a much lower bacterial load, thus has decreased concentration of potential carcinogens from bile acid breakdown [23]. Authors evocated rapid turnover of the small bowel mucosa which inhibits the growth of cancer cells, high concentration of microsomal hydrolases likely to inactivate some carcinogens and high level of $\mathrm{Ig} \mathrm{A}$, that is evidence of an important anti-virus activity. Meaning these tumors are more frequent in patients with congenital or acquired immuno-deficiency [23-25]. Studies also demonstrate that the small intestine generates less endogenous reactive oxidative species (ROS) than the colon does, which may handle oxidative stress more effectively than the colon resulting in less oxidative damage during exogenous oxidant stress [26].

Males are more likely to be diagnosed with, and die from, small intestine cancer than females [6]. In our study, the male sex was represented by 24 cases $(51.06 \%)$ or $1.71 \%$ of all digestive cancers. The sex ratio was 1.04:1. In Japan, Terada found that the male to female ratio was 14: 8 [27] and in Morocco - 1.6:1 [28]. The gender discrepancy in incidence is about 1.3:1 and in mortality about 1.6:1, suggesting lower survival rates among men [16]. Interestingly, in the United Kingdom, while men are still more likely to be diagnosed, survival rates for men are actually higher than those for women [29]. But, in some African countries, researchers found a female predominance, such like in Togo $(0.6: 1)$, Madagascar (0.76:1) and Tunisia (0.81:1). However, it is important to note the low number of cases in those studies 8 , 25 and 20 respectively [8, 9, 30]. Differences in diet, carcinogen exposure, and metabolic rate, among others, may underlie the sex difference in small intestine bowel incidence and mortality [6].

The median age for small intestine cancer diagnosis we found was $49,77 \pm 15,84$ (11 to 78 years). In some others African countries, the average age was 46 years $(15-70$ years), 41,75 years (5 et 77 years) and 36 years old, in Morocco, Togo and Madagascar respectively [7-9]. In the USA, the median age was 66 [3]. The majority of our patients were between 50 and 59 years old (11 cases; $23.40 \%$ ). The most common age for incidence in the United Kingdom was 80-84 [29].

Some factors are classified like Non-Modifiable Risk Factors. Around $1 \%$ of people with larger $(20 \mathrm{~mm}+)$ adenomas, or adenomas with high-grade dysplasia, develop bowel cancer within 4 years after removed adenomas [10]. As in the colon, adenoma in the small intestine appears to be a precursor of adenocarcinoma [31]. A large fraction of villous adenomas of the small intestine has been shown to progress to malignancy [32]. Villous histology, increasing size and a higher grade of dysplasia of the adenoma increase the risk of neoplastic transformation from adenoma to carcinoma [31, 33].

The risk of advanced bowel cancer is $80 \%$ higher in people with low-risk polyps detected at first colonoscopy, compared with people with no polyps detected at first colonoscopy [34]. Those with familial adenomatous polyposis (FAP) have a germline APC mutation that predisposes towards the 
growth of adenoma polyps. Familial adenomatous polyposis (FAP) is an autosomal dominant genetic disorder caused by mutations of the APC gene on the long arm of chromosome 5. Patients with FAP have thousands of polyps growing in their intestinal lining by the age of 10-12. Over time, the risk of these adenomas transforming to adenocarcinoma grows exponentially, and by age 40 , virtually all patients with FAP will have received a colorectal cancer diagnosis $[35,36]$. In our study, many patients developed polyps; $25 \%$ had polyposis, $12.5 \%$ adenomatous polyps. The small intestine is the second most common site for adenocarcinoma among those with FAP. In a study of 1255 patients, about 5\% had been diagnosed with small bowel adenocarcinoma (SBA). Half of those cancers were found in the duodenum [11]. The risk of small intestine adenocarcinoma among those with FAP is 330 times higher than for the general population [37, 38]. The prevalence of duodenal adenomatosis in FAP patients are $50 \%-90 \%$ and $3 \%-5 \%$ of these patients develop duodenal cancer; however, periampullary adenomas seem to have a high risk of malignant transformation [39].

In our series, we found that $12.5 \%$ of patient consumed delicatessen. Dietary factors have been suggested to be related to the risk of small bowel cancer. Diets that have a high content of animal fat and protein have been associated with a higher risk of that pathology with correlation coefficients of 0.61 and 0.75 , respectively [40]. Chow et al observed two-to three-fold increases in SBC risk with frequent intake of red meat and salt-cured/smoked foods [41]. Others authors reported a significant increase in risk associated with frequent intake of foods rich in heterocyclic aromatic amines (based on the combined intake of fried bacon and ham, barbecued and/or smoked meat and smoked fish) in males only and with total sugar intake [42]. Processed meat was designated as a carcinogen, and red meat as a probable carcinogen, due to their likely effect on the development of cancers of the small and large intestine [43].

A few studies have observed a positive association between alcohol consumption and SBC, either adenocarcinoma or carcinoid tumors [42, 44]. In our study, $12.5 \%$ of patients recognized their alcohol consumption. Several studies do not find a relationship between alcohol intake and SBC risk [41, 45, 46]. Heavy alcohol consumption had been found to increase the risk of CRC by $20-40 \%$, leading many to assume it has a similar effect on SBA, even if small sample sizes due to the rarity of the disease preclude definitive results $[6,47]$.

Many factors have been suggested to be a risk factor or promoter of SBC, such as Inflammatory bowel diseases, Celiac disease, Peutz-Jeghers syndrome, other cancers, [31, 48-50].

SBC can be found in different locations. According to Hatzaras et al findings, the most prevalent anatomical tumor site in this study was the ileum (374 cases; $29.7 \%$ ), followed by the duodenum (320 cases; $25.4 \%$ ), and then the jejunum, affected in 193 cases (15.3\%) [51]. Raharisolo Vololonantenaina et al found $50 \%$ in duodenum, $10 \%$ in jejunum, $25 \%$ in ileum and $15 \%$ diffuse repartition. In
Tunis, in their series Haoues et al discovered Malignant tumors of the small bowel most commonly arise in the ileum $(60 \%)$ followed by the jejunum (35\%) [30]. In our study the tumor was ileum localization in $47.37 \%$ of cases, jejunum - 36.84\% and $15.79 \%$ - duodenum. This site dispersion is particularly interesting and may be explained by the fact that the segments of the small bowel in proximity to the stomach and large bowel are exposed to higher concentrations of carcinogens [51]. Other possible mechanisms for explanation of this phenomenon are that the jejunum may be protected by the continuous and rapid turnover of its epithelial cells (life span range, 2-5 days), which confers a unique resiliency of this part of the bowel and that the jejunal mucosa has an enhanced ability to digest, metabolize, and/or detoxify potential carcinogenic byproducts of dietary ingestion [41].

Adenocarcinoma (33 cases, 70.21\%) was the most common histological type in our study, followed by NonHogdkin's Malignant Lymphoma (NHML). Carcinoid was found principally before 40 and after 70 years old. Instead of that, all tumors showed a predilection for the ileum. Hatzaras et al histologically, discovered that carcinoid tumors were the predominant form of small-bowel neoplasms (417 cases; $33 \%$ ), followed by adenocarcinomas (379 cases; $30.1 \%$ ) and, all tumors showed a predilection for the ileum, with the exception of adenocarcinoma, for which the highest incidence was in the duodenum and then progressively decreased throughout the rest of the more distal small intestine [51]. For Haoues et al, carcinoid tumor was the main histological type (8 cases), followed by leiomyosarcoma ( 7 cases), giant B-cell lymphoma ( 2 cases), malignant stromal tumor ( 2 cases) and malignant myxoid schwannoma (1 case). However, according to many authors, approximately $30 \%-40 \%$ of the cancers observed in the small intestine are adenocarcinomas, a percentage much lower than the proportion in the colon where the overwhelming majority is adenocarcinomas. Most of the tumors located in the duodenum and the duodenal-jejunal junction are adenocarcinomas [5, 14, 33]. Carcinoid tumors accounts for some $35 \%-42 \%$ of neoplasms in the small intestine, most of which occur in the ileum and rarely in the duodenum $[5,14$, 33]. About $15 \%-20 \%$ of cancers of the small intestine are lymphomas with most occurring in the ileum and jejunum [5, 14]. Some authors attributed the prevalence of adenocarcinoma in the duodenum to the early metabolism of ingested carcinogens and the interactions of carcinogens with pancreaticobiliary secretions [52]. Ribeiro et al 11 reported a significant exception in patients with long-standing Crohn disease. Seventy percent of the patients that develop a change in their clinical status, such as small-bowel obstruction refractory to usual treatment, were found to have developed an adenocarcinoma of the ileum at the site of the primary inflammatory process [12].

\section{Conclusion}

Cancers of the small intestine are is the sixth malignant 
tumor of the digestive tract in Cameroon. The mean age of onset is 49.77 years old with a relative male predominance. They are comprised of 3 major histological types (adenocarcinomas, Non-Hogdkin's Malignant Lymphoma and Carcinoid), the most common is adenocarcinoma. The establishment of a real cancer registry will provide better coordination in the control of the epidemiology of this pathology, and in the development of means to fight it.

\section{References}

[1] Raghav K, Overman MJ (2013) Small bowel adernocarcinomas existing evidence and evolving paradigms. Nat Rev Clin Oncol 10: 534-544.

[2] Siegel RL, Miller KD, Jemal A (2018) Cancer statistics 2018. CA Cancer J Clin 68: 7-30.

[3] Surveillance, Epidemiology, and End Results (SEER) Program. SEER*Stat Database: Incidence-SEER 18 Regs Research Data+Hurricane Katrina Impacted Louisiana Cases, Nov 2015 Sub (1973-2013 Varying) —Linked To County Attributes-Total U.S., 1969-2014 Counties, National Cancer Institute, DCCPS, Surveillance Research Program, Surveillance Systems Branch, Released April 2016, Based on the November 2015. Available online: $\mathrm{https} / / /$ seer.cancer.gov/statfacts/html/smint.html (accessed on 15 February 2019).

[4] Curado MP, Edwards B, Shin HR, Storm H, Ferlay J, Heanue M, Boyle P. Cancer Incidence in Five Continents Vol. IX. Lyon: IARC, IARC Scientific Publication, No. 160, 2007.

[5] Haselkorn T, Whittemore AS, Lilienfeld DE. Incidence of small bowel cancer in the United States and worldwide: geographic, temporal, and racial differences. Cancer Causes Control. 2005; 16: 781-787.

[6] Barsouk A, Rawla P, Barsouk A, Thandra KC. Epidemiology of Cancers of the Small Intestine: Trends, Risk Factors, and Prevention. Med. Sci. 2019; 7: 46; doi: 10.3390/medsci7030046.

[7] Halima A, Maha M, Issam L, Hind M, Hassan E. Les tumeurs malignes primitives de l'intestin grêle: aspects cliniques et thérapeutiques de 27 patients. Pan African Medical Journal. 2011; 8: 18 .

[8] Ayite A, Dosseh E, Etey K, Senah K, Napo-Koura K, James K. Les Cancers De L'intestin Grêle Au Chu De Lomé (Togo). A Propos De 8 Cas Observes En 10 Ans. Médecine d'Afrique Noire: 1996, 43 (10): 535-7.

[9] Raharisolo Vololonantenaina CR, Dina TJN, Ravalisoa A. Un cancer peu fréquent: celui de l'intestin grêle. A propos de 25 cas diagnostiqués à l'Institut Pasteur de Madagascar de 1992 à 2001. Arch Inst Pasteur de Madagascar. 2003; 69 (1 \& 2): 8286.

[10] Martínez ME, Baron JA, Lieberman DA, et al. A pooled analysis of advanced colorectal neoplasia diagnoses after colonoscopic polypectomy. Gastroenterology. 2009; 136 (3): 832-41.

[11] Jagelman DG, DeCosse JJ, Bussey HJ. Upper gastrointestinal cancer in familial adenomatous polyposis. Lancet. 1988; 1 : $1149-1151$.
[12] Ribeiro MB, Greenstein AJ, Heimann TM, Yamazaki Y, Aufses AH Jr. Adenocarcinoma of the small intestine in Crohn's disease. Surg Gynecol Obstet. 1991173: 343-349.

[13] Carbonnel F, Grollet-Bioul L, Brouet JC, et al. Are complicated forms of celiac disease cryptic T-cell lymphomas? Blood 1998; 92: 3879-3886.

[14] Bilimoria KY, Bentrem DJ, Wayne JD, Ko CY, Bennett CL, et al. Small bowel cancer in the United States: Changes in epidemiology, treatment, and survival over the last 20 years. Ann. Surg. 2009; 249: 63-71.

[15] Moon YW, Rha SY, Shin SJ, Chang H, Shim HS, Roh JK. Adenocarcinoma of the small bowel at a single Korean institute: Management and prognosticators. J. Cancer Res. Clin. Oncol. 2010; 136: 387-394.

[16] Ngowe Ngowe M, Essomba A, Angwafo III F, Binam F, Sosso AM. Les tumeurs de l'intestin grele a l'hopital general de yaounde: à propos de 10 cas. Médecine d'Afrique noire 48 (12): 491_495.

[17] Collins, J. T.; Badireddy, M. Anatomy, Abdomen and Pelvis, Small Intestine. In StatPearls; StatPearls Publishing LLC.: Treasure Island, FL, USA, 2018.

[18] Neugut, A. I.; Jacobson, J. S.; Suh, S.; Mukherjee, R.; Arber, $\mathrm{N}$. The epidemiology of cancer of the small bowel. Cancer Epidemiol. Biomark. Prev. 1998, 7, 243-251.

[19] Jemal A, Siegel R, Ward E, Hao Y, Xu J, Thun MJ. Cancer statistics, 2009. CA Cancer J Clin 2009; 59: 225-249.

[20] Canadian Cancer Society. Canadian Cancer Statistics 2009. Canadian Cancer Society, Toronto, Canada, 2009.

[21] Lien G, Mori M, Enjoji M. Primary carcinoma of the small intestine. A clinicopathologic and immunohistochemical study. Cancer. 1988; 61: 316-323.

[22] Lowenfels AB. Why are small-bowel tumours so rare? Lancet. $1973 ; 1: 24-25$

[23] Arber N, Neugut AI, Weinstein IB, Holt P. Molecular genetics of small bowel cancer. Cancer Epidemiol Biomarkers Prev 1997; 6: 745-748.

[24] Gabos S, Berkel J, Band P, Robson D, Whittaker H. Small bowel cancer in Western Canada. International Journal of Epidemiology. 1993; 22: 198-206.

[25] Turowski G, Abasson D. Primary malignant lymphoma of the intestine. The American Journal of Surgery. 1995; 169: 433441.

[26] Sanders LM, Henderson CE, Hong MY, Barhoumi R, Burghardt RC, Carroll RJ, Turner ND, Chapkin RS, Lupton JR. Pro-oxidant environment of the colon compared to the small intestine may contribute to greater cancer susceptibility. Cancer Lett 2004; 208: 155-161.

[27] Terada T. Malignant tumors of the small intestine: A histopathologic study of 41 cases among 1,312 consecutive specimens of small intestine. Int J Clin Exp Pathol 2012; 5 (3): 203-209.

[28] Rabbani K, Narjis Y, Fouad, Samlani Z, Difaa A, et al. Primary malignancies of the small bowel at the Marrakech Teaching Hospital: a report of 52 cases. J. Afr. Cancer. 2012; 4: 84-88. 
[29] Cancer Registration Statistics, England Statistical Bulletins. Available online: https://www.ons.gov.uk/peoplepopulationandcommunity/healt handsocialcare/conditionsanddiseases/bulletins/cancerregistrat ionstatisticsengland/previousReleases (accessed on 16 February 2019).

[30] Haoues N, Mabrouk M, Zaafouri H, Noomene R, Bouhafa A, et al. Primary cancers of the small bowel: About 20 cases. Open Journal of Gastroenterology. 2014; 4: 81-87.

[31] Gill SS, Heuman DM, Mihas AA. Small intestinal neoplasms. J Clin Gastroenterol 2001; 33: 267-282.

[32] Bjork KJ, Davis CJ, Nagorney DM, Mucha P Jr. Duodenal villous tumors. Arch Surg 1990; 125: 961-965.

[33] Schottenfeld D, Beebe-Dimmer JL, Vigneau FD. The epidemiology and pathogenesis of neoplasia in the small intestine. Ann Epidemiol 2009; 19: 58-69.

[34] Hassan C, Gimeno-García A, Kalager M, et al. Systematic review with meta-analysis: the incidence of advanced neoplasia after polypectomy in patients with and without lowrisk adenomas. Aliment Pharmacol Ther. 2014; 39 (9): 90512 .

[35] Groden J, Thliveris A, Samowitz W, Carlson M, Gelbert L, Albertsen H, Joslyn G, Stevens J, Spirio L, Robertson M. Identification and characterization of the familial adenomatous polyposis coli gene. Cell 1991; 66: 589-600.

[36] De Rosa M, Pace U, Rega D, Costabile V, Duraturo F, et al. Genetics, diagnosis and management of colorectal cancer (Review). Oncol. Rep. 2015; 34: 1087-1096.

[37] Offerhaus GJ, Giardiello FM, Krush AJ, Booker SV, Tersmette AC, et al. The risk of upper gastrointestinal cancer in familial adenomatous polyposis. Gastroenterology 1992, $102,1980-1982$.

[38] Shenoy S. Genetic risks and familial associations of small bowel carcinoma. World J. Gastrointest. Oncol. 2016; 8: 509519.

[39] Kadmon M, Tandara A, Herfarth C. Duodenal adenomatosis in familial adenomatous polyposis coli. A review of the literature and results from the Heidelberg Polyposis Register. Int J Colorectal Dis 2001; 16: 63-75.

[40] Lowenfels AB, Sonni A. Distribution of small bowel tumors. Cancer Lett. 1977; 3: 83-86.

[41] Chow WH, Linet MS, McLaughlin JK, Hsing AW, Chien HT,
Blot WJ. Risk factors for small intestine cancer. Cancer Causes Control 1993; 4: 163-169.

[42] Wu AH, Yu MC, Mack TM. Smoking, alcohol use, dietary factors and risk of small intestinal adenocarcinoma. Int $\mathrm{J}$ Cancer. 1997; 70: 512-517.

[43] International Agency for Research on Cancer. List of Classifications by cancer sites with sufficient or limited evidence in humans, Volumes 1 to 117 . Accessed January 2017.

[44] Chen CC, Neugut AI, Rotterdam H. Risk factors for adenocarcinomas and malignant carcinoids of the small intestine: preliminary findings. Cancer Epidemiol Biomarkers Prev 1994; 3: 205-207.

[45] Negri E, Bosetti C, La Vecchia C, Fioretti F, Conti E, Franceschi S. Risk factors for adenocarcinoma of the small intestine. Int J Cancer 1999; 82: 171-174.

[46] Hassan MM, Phan A, Li D, Dagohoy CG, Leary C, Yao JC. Risk factors associated with neuroendocrine tumors: A U.S.based case-control study. Int J Cancer 2008; 123: 867-873.

[47] Bagnardi V, Rota M, Botteri E, Tramacere I, Islami F, et al. Alcohol consumption and site-specific cancer risk: A comprehensive dose-response meta-analysis. Br. J. Cancer. 2015; 112: 580-593.

[48] Kodaira C, Osawa S, Mochizuki C, Sato Y, Nishino M, Yamada T, Takayanagi Y, Takagaki K, Sugimoto K, Kanaoka S, Furuta T, Ikuma M. A case of small bowel adenocarcinoma in a patient with Crohn's disease detected by PET/CT and double-balloon enteroscopy. World J Gastroenterol 2009; 15: 1774-1778.

[49] Green PH, Cellier C. Celiac disease. N Engl J Med 2007; 357 : 1731-1743.

[50] Ripley D, Weinerman BH. Increased incidence of second malignancies associated with small bowel adenocarcinoma. Can J Gastroenterol 1997; 11: 65-68.

[51] Hatzaras I, Palesty JA, Abir F, Sullivan P, Kozol RA, et al. Small-Bowel Tumors: Epidemiologic and Clinical Characteristics of 1260 Cases From the Connecticut Tumor Registry. Arch Surg. 2007; 142: 229-235.

[52] Ross RK, Hartnett NM, Bernstein L, Henderson BE. Epidemiology of adenocarcinomas of the small intestine: is bile a small bowel carcinogen? Br J Cancer. 1991; 63: 143145. 